\title{
PELATIHAN PEMBUATAN HANDICRAFT DARI LIMBAH RUMAH TANGGA ANORGANIK UNTUK MENINGKATKAN KETRAMPILAN DAN INCOME IBU-IBU DESA BLIMBINGAN
}

\author{
Ninda Beny Asfuri, Luncana Faridhoh Sasmito \\ Universitas Tunas Pembangunan (UTP) Surakarta \\ nindaarjuna@gmail.com
}

\begin{abstract}
Waste of household waste becomes a problem in the environment of Blimbingan village because there are many household waste waste that accumulate and pollute the surrounding environment. Household needs products mostly plastic waste where plastic waste (inorganic) handling is relatively more complicated than organic waste, because inorganic waste can not be degradable naturally. Inorganic garbage originating from the household of Blimbingan village various such as plastic waste packaging of a household products, Kresek, aqua bottles are many of which are not utilized and only dumped in the trash. The villagers of Blimbingan, Baturan, especially mothers are less aware of the dangers posed by each day they continue to throw away their household garbage. This dedication activities aims to provide counselling and training of handicraft-value, valuable and economical value by utilizing household waste in Blimbingan village and provide guidance on how to sell to increase family income and can be a new job opportunities for the mothers of the village Blimbingan, Baturan. The methods used in this activity are by counseling, training/practice, monitoring and mentoring. Based on several series of events can be concluded that (1) of all participants carried out in the home mom Lurah in Blimbingan village is increased by $95 \%$ in terms of understanding and mastery of handicraft-like bags, flowers made, plastic bottles used for the category of good pencils. (2) teamwork and mothers are very compact and extraordinary proven to always attend training well until the event is over
\end{abstract}

Keywords: Household waste, Handicraft

\begin{abstract}
Abstrak
Limbah sampah rumah tangga menjadi problem di lingkungan Desa Blimbingan karena banyak sekali limbah sampah rumah tangga yang menumpuk sehingga mencemari lingkungan sekitar. Produk kebutuhan rumah tangga kebanyakan sampah plastik dimana sampah plastik (anorganik) penanganannya relatif lebih rumit daripada sampah organik, karena sampah anorganik tidak dapat terurai secara alami. Sampah anorganik yang berasal dari rumah tangga desa Blimbingan bermacam-macam seperti sampah plastik bekas kemasan suatu produk keperluan rumah tangga, kresek, botol plastik aqua banyak sekali yang tidak dimanfaatkan dan hanya dibuang di tempat sampah. Warga desa Blimbingan, Baturan terutama ibu-ibu kurang sadar akan bahaya yang ditimbulkan apabila setiap hari mereka terus membuang sampah rumah tangganya. Kegiatan pengabdian ini bertujuan memberikan penyuluhan serta pelatihan pembuatan kerajinan bernilai seni, bernilai guna dan bernilai ekonomis dengan memanfaatkan limbah rumah tangga yang ada di Desa Blimbingan serta memberikan bimbingan cara menjual agar bisa menambah income keluarga dan bisa menjadi peluang kerja baru bagi ibu-ibu Desa Blimbingan, Baturan. Metode yang digunakan dalam kegiatan ini adalah dengan penyuluhan, pelatihan/praktek, monitoring dan pendampingan. Berdasarkan beberapa rangkaian kegiatan pengabdian dapat ditarik kesimpulan bahwa (1) Dari seluruh peserta yang dilaksanakan di rumah ibu lurah di Desa Blimbingan ini mengalami peningkatan sebesar $95 \%$ dalam hal pemahaman serta penguasaan ketrampilan pembuatan handicraft seperti kresek dibuat bunga, botol plastik bekas dibuat tempat pensil, pot bunga dalam kategori baik. (2) Kerjasama tim dan ibu-ibu sangat kompak dan luar biasa terbukti selalu menghadiri pelatihan dengan baik sampai acara selesai
\end{abstract}

Kata Kunci: Limbah Sampah Rumah Tangga, Handicraft 


\section{Pendahuluan}

Desa Blimbingan merupakan salah satu desa di Kelurahan Baturan, Kecamatan Colomadu, Kabupaten Karanganyar dengan jumlah penduduk 152 jiwa atau 38 KK. Mata pencaharian utama warga desa ini adalah swasta, pabrik, penjahit dan ibu rumah tangga. Sebagian besar warga desa Blimbingan, Baturan kurang memiliki pengetahuan dan keterampilan yang memadai sehingga mereka kurang bisa mendayagunakan sesuatu yang ada di sekitar misal sampah rumah tangga menjadi sesuatu yang berdaya guna (handicraft). Berdasarkan wawancara dengan beberapa warga Desa Blimbingan bahwa Desa Blimbingan mempunyai banyak sampah limbah rumah tangga yang dihasilkan oleh ibu-ibu setiap harinya dalam aktivitas rumah tangganya sehingga menyumbang sampah yang cukup signifikan setiap harinya, terutama sampah anorganik

Limbah rumah tangga menjadi problem di lingkungan Desa Blimbingan Baturan karena banyak sekali limbah sampah rumah tangga yang menumpuk sehingga mencemari lingkungan sekitar. Produk kebutuhan rumah tangga kebanyakan sampah plastik dimana sampah plastik (anorganik) penanganannya relatif lebih rumit daripada sampah organik, karena sampah anorganik tidak dapat terurai secara alami. Sampah anorganik yang berasal dari sampah rumah tangga desa Blimbingan, Baturan bermacam-macam seperti sampah plastik bekas kemasan suatu produk keperluan rumah tangga, kresek, botol plastik aqua banyak sekali yang tidak dimanfaatkan dan hanya dibuang di tempat sampah.

Warga desa Blimbingan, Baturan terutama ibu-ibu kurang sadar akan bahaya yang ditimbulkan apabila setiap hari mereka terus membuang sampah rumah tangganya. Apabila tidak bisa kita atasi dengan baik maka beberapa tahun ke depan maka hal ini jelas akan mengancam generasi penerus kita. Padahal kalau mereka bisa memanfaatkan limbah rumah tangga hal tersebut bisa mendatangkan nilai tambah yaitu bisa diolah menjadi handicraft yang berguna untuk diri sendiri dan juga bisa dijual dipasaran asalkan mau berlatih dan mau menekuni membuat handicraft. Limbah rumah tangga yang bisa dibuat handicraft seperti bungkus molto, kecap, minuman bisa dibuat tas, botol plastik bisa dibuat pot bunga dan tempat pensil, kantung kresek warna-warni bisa dibuat menjadi bunga yang indah, sehingga akan menambah income dari limbah rumah tangga tersebut. Ibu-Ibu selaku ibu rumah tangga mempunyai peran kunci dalam mengelola sampah karena mereka yang sehari-hari menangani sampah dari rumah tangga dan pengolahannya.

Kurang sadarnya akan pemanfaatan limbah rumah tangga oleh warga desa Blimbingan, Baturan membuat tim pengabdian tergerak untuk membantu masyarakat agar sadar terhadap lingkungan sekitar dengan memberi edukasi dengan gaya hidup ramah lingkungan seperti reduce, reuse, recycle dan salah satu caranya dengan memanfaatkan sampah rumah tangga yang menumpuk menjadi barang yang bermanfaat dan mempunyai nilai guna serta nilai ekonomis. Hal ini sejalan dengan pendapat (Aminudin dan Nurwati, 2019: 67) jika mau mengelola sampah dengan serius dan dengan cara baik dan benar dan bahkan profesional maka sampah bukanlah masalah. Sampah bahkan dapat menghasilkan sesuatu yang dapat kita manfaatkan dan mendatangkan penghasilan (uang). Adanya kepedulian dari ibu rumah tangga juga akan meminimalkan sampah rumah tangga tentunya akan sangat membantu meminimalkan timbunan sampah 
keseluruhan yang masuk ke lingkungan serta ikut berpartisipasi menanamkan program go green. Dari hasil survei di lokasi dalam pengumpulan limbah sampah rumah tangga dibantu warga sekitar dan ternyata benar dalam sehari banyak limbah rumah tangga yang terkumpul. Dengan begitu dalam satu bulan bisa dibayangkan jumlah limbah sampah rumah tangga yang menumpuk. Maka dari permasalahan tersebut tim pengabdian memberi solusi penanganan dengan merencanakan akan memberi pelatihan kepada ibuibu Desa Blimbingan, Baturan untuk berkreasi membuat handicraft dengan dibantu tim, disamping pelatihan pembuatan handicraft akan dijelaskan juga mengenai cara pemasaran produk agar produk laku dipasaran. Untuk pemasaran dipasarkan lewat media sosial yang tentunya sudah familiar di masyarakat seperti lewat whattsap, instagram, sehingga masyarakat luas lebih mengenal produk yang dijual. Kedepannya diharapkan usaha produk limbah sampah rumah tangga menjadi handicraft ini menjadi usaha ekonomi produktif. Keunggulan produk ini yaitu modal yang digunakan sedikit dan tentunya hasilnya menakjubkan sehingga bisa menambah penghasilan asalkan mau menekuni dan mau selalu berinovasi dan berkreasi.

\section{Metode}

Metode pelaksanaan kegiatan pengabdian dengan cara penyuluhan (penjelasan teoritis) dengan porsi $20 \%$ dan kegiatan praktek dengan porsi $80 \%$. Tahap-tahap kegiatan meliputi sosialisasi, dilanjut praktek, monitoring dan pendampingan. Khalayak sasaran yaitu ibu-ibu Desa Blimbingan,Baturan Kecamatan Colomadu, Kabupaten Karanganyar. Kegiatan diawali dengan penyuluhan yang bertujuan untuk memberikan penjelasan secara teoritis mengenai kegiatan yang akan dipraktekkan. Pada kesempatan ini diberikan penjelasan serta pelatihan mengenai limbah sampah anorganik rumah tangga yang tadinya tidak berguna bisa dijadikan barang bernilai seni, bernilai guna tinggi serta mempunyai daya jual serta di beri penjelasan mengenai pemasarannya. Peserta dimotivasi agar tumbuh kesadaran untuk berperan dalam memecahkan permasalahan yang dihadapi dan upaya pemanfaatan limbah rumah tangga yang makin hari makin menumpuk menjadi barang yang bermanfaat dan bernilai ekonomi. Peserta juga dimotivasi meningkatkan semangat berwirausaha untuk meningkatkan kesejahteraan keluarga. Kegiatan praktek berupa cara membuat handicraft dari limbah rumah tangga seperti diajarkan cara pembuatan tempat pensil, pot bunga, bunga dari sampah rumah tangga. Misalnya bunga dari plastik bekas yang tidak terpakai, tempat pensil dan pot bunga dari botol bekas. Alat dan bahan yang digunakan untuk membuat pot bunga dan tempat pensil yaitu botol bekas, spidol, pisau cutter, gunting, cat akrilik, kuas. Cara pembuatannya yaitu 1) Lepas label bagian luar botol dan juga bersihkan bagian luar botol 2) Gambar pola yang kalian inginkan misal hewan yang disukai menggunakan spidol biasa 3) Gunting botol sesuai pola yang sudah dibuat, apabila ada bagian yang sulit dibentuk gunakan pisau cutter agar lebih rapi 4) Apabila sudah terbentuk polanya warnai dengan cat akrilik, warnai dasarnya terlebih dahulu 5) Biarkan kering terlebih dahulu 6) Apabila warna dasarnya sudah kering, gambar wajah hewan yang sudah dipilih menggunakan spidol permanen 7) Diamkan dan tunggu sampai kering.

Pembuatan handicraft selain dapat digunakan sendiri sebagai hiasan dirumah dan untuk keperluan sendiri, juga dapat dikembangkan agar bisa menjadi usaha ekonomi 
sehingga bisa menambah income rumah tangga. Untuk itu diberikan juga bimbingan cara pemasaran dan manajemen usaha. Peserta/mitra selaku kelompok sasaran antara yang strategis diharapkan mampu menularkan pengetahuan dan keterampilan yang didapat dari kegiatan ini kepada kelompok atau warga desa lainnya.

\section{Hasil dan Pembahasan}

Pelatihan ini memberikan beberapa materi yang terkait pelatihan pembuatan handicraft dari limbah sampah rumah tangga. Materi yang tersajikan sebanyak 3 (tiga) bahasan yang masing-masing disajikan oleh anggota Tim Pengabdi sesuai bidang yang bersangkutan. Pelaksanaan program ini melibatkan 2 dosen agar kegiatan dapat berjalan lancar. Kegiatan tanya jawab dilakukan bersamaan dengan penyajian materi. Para peserta langsung berdiskusi dengan para pemateri secara langsung untuk memahamkan materi dan sharing pengalaman terkait dengan masalah yang tengah dibahas dalam materi bersangkutan. Dari seluruh peserta yang dilaksanakan di rumah ibu lurah di Desa Blimbingan ini mengalami peningkatan sebesar $95 \%$ dalam hal pemahaman serta penguasaan ketrampilan pembuatan handicraft seperti kresek dibuat bunga, botol plastik bekas dibuat tempat pensil dan pot bunga kategori baik. Para peserta dari hari ke hari semakin terampil dalam membuat handicraft.

Evaluasi kegiatan pengabdian masyarakat ini dilakukan dengan beberapa cara. Evaluasi hasil dilihat dari tugas praktik para peserta yang ada. Hasil praktiknya dinilai dan hal itu menggambarkan keberhasilan materi yang telah disajikan. Selain itu, secara proses juga dicermati kinerja dan kesertaan para peserta. Di akhir kegiatan Tim menjaring data kebermaknaan program pada para peserta. Berdasarkan hasil produk berupa handicraft seperti bunga, tempat pensil, pot secara umum para peserta telah mampu memahami materi mengenai alat dan bahan yang digunakan untuk pembuatan handicraft, cara pembuatan handicraft dari limbah sampah rumah tangga serta cara pemasaran produk.

Evaluasi kegiatan yang dilakukan selama proses kegiatan berlangsung, yaitu pada saat peserta kegiatan melaksanakan proses pembuatan serta pemasaran dengan dipantau tim pengabdi. Teknik evaluasi dilakukan dengan cara observasi, yaitu melihat bagaimana kualitas handicraft yang dihasilkan. Rata-rata para peserta telah mampu membuat handicraft dengan baik dan mampu memasarkan produk dimedia online serta di titipkan di pasar.

Beberapa faktor pendukung dan penghambat dalam kegiatan ini antara lain:

1. Faktor Pendukung

Kegiatan Pengabdian pada Masyarakat ini telah terlaksana dengan baik berkat dukungan berbagai faktor yaitu:

a. Komunikasi dan koordinasi tim

Komunikasi antar anggota tim berlangsung lancar dan efektif sehingga koordinasi tim pada proses persiapan, pembagian tugas, dan pelatihan dapat berlangsung dengan baik dan tepat waktu. Hal ini juga didukung kompetensi tim pengabdi dalam bidang yang diajarkan memadai sehingga tidak ada permasalahan yang mempersulit jalannya pelatihan karena semua permasalahan terkait dengan materi serta alat bahan dapat terselesaikan sehingga ibu-ibu Desa Blimbingan benar-benar terbimbing dengan baik

b. Komitmen peserta pelatihan

Peserta pelatihan yang terdiri dari kelompok ibu-ibu Desa Blimbingan sangat 
antusias dan bersemangat dalam mengikuti pelatihan dari awal hingga akhir. Begitu pula saat penugasan dimana ibu-ibu Desa Blimbingan tersebut diminta untuk membuat sendiri handicraft, seperti kresek dibuat bunga, botol plastik bekas dibuat tempat pensil seperti yang diajarkan, mereka sangat bersemangat untuk bekerja dan menanyakan segala sesuatu terkait hal yang mereka kerjakan.

c. Penerimaan yang Baik dari Masyarakat

Semangat peserta sangat besar dan mendukung kegiatan serta menyambut baik, serta berharap dapat dilibatkan lagi dalam pelatihan-pelatihan yang akan datang.

2. Faktor Penghambat

Keterbatasan waktu juga sangat terkait dengan keterbatasan biaya, akan tetapi jumlah tatap muka dirasa cukup memadai sehingga pelatihan ini menjadi lebih bermakna dan bermanfaat dalam memberikan pemahaman dan keterampilan bagi peserta. Antusiasme peserta menjadikan mereka merasa waktu pelatihan terlalu singkat karena harus berakhir di saat peserta telah mulai memahami materi.

\section{Kesimpulan}

1. Dari seluruh peserta yang dilaksanakan di rumah ibu lurah di Desa Blimbingan ini mengalami peningkatan sebesar $95 \%$ dalam hal pemahaman serta penguasaan ketrampilan pembuatan handicraft seperti kresek dibuat bunga, botol plastik bekas dibuat tempat pensil dan pot bunga kategori baik.

2. Kerjasama tim dan ibu-ibu sangat kompak dan luar biasa terbukti selalu menghadiri pelatihan dengan baik sampai acara selesai.

\section{Daftar Pustaka}

Aminudin dan Nurwati. (2019). Pemanfaatan Sampah Plastik Menjadi Kerajinan Tangan Guna Meningkatkan Kreatifitas Warga Sekitar ITB AD Jakarta. Jurnal Abdimas BSI, 2(1), 66-79.

Fatoni, Nur, dkk. (2017). Pendayagunaan Sampah Menjadi Produk Kerajinan. Dimas, 17(1).

Warsito, Budi, dkk. (2018). Pelatihan Pemanfaatan Sampah Plastik Berpotensi Ekonomis bagi Nasabah Bank Sampah Sempulur Asri. Proseding Seminar Nasional Unimus, Vol 1, e-ISSN: 2654-3257, p-ISSN:2654-3168. 